\title{
РОЛЬ НОВИХ ТЕХНОЛОГІЙ У САМОПІДГОТОВЦІ СТУДЕНТІВ- СТОМАТОЛОГІВ ДО ЛІЦЕНЗІЙНОГО ІНТЕГРОВАНОГО ІСПИТУ “КРОК 1. СТОМАТОЛОГІЯ" ЗА КРЕДИТНО-МОДУЛЬНОЇ СИСТЕМИ ОРГАНІЗАЦІЇ НАВЧАЛЬНОГО ПРОЦЕСУ
}

І. Ю. Олійник

Буковинський державний медичний університет (Чернівиі)

\author{
ROLE OF NEW TECHNOLOGIES IN SELF-PREPARATION OF \\ STUDENTS-DENTISTS FOR THE LICENSE INTEGRATED \\ EXAMINATION "KROK 1. DENTISTRY" BY THE CREDIT-MODULAR \\ SYSTEM OF THE ORGANIZATION OF EDUCATIONAL PROCESS
}

I. Yu. Oliynyk

\author{
Bukovynian State Medical University (Chernivtsi)
}

\begin{abstract}
У статті проведено аналіз ефективності застосування системи дистанційного навчання "Мооdle" для самопідготовки студентів-стоматологів до складання ліщензійного інтегрованого іспиту “Крок 1. Стоматологія”.
\end{abstract}

The article analyzed the efficiency of application of system of remote training "Moodle" for self-preparation of dental students for passing the license integrated examination "Krok 1. Dentistry".

Вступ. Навчальний процес, як складова частина загального процесу виховання всебічно розвиненої особистості, що відповідає потребам сучасного суспільства, повинен забезпечити реалізацію трьох функцій: освітньої, розвиваючої та виховної [1]. Підвищення освітнього рівня лікаря, як фактора його конкурентоспроможності, на сучасному етапі є одним із основних завдань вищої медичної освіти та зумовлює високі вимоги до якості підготовки спеціалістів медичного профілю. У цьому ключі одним із пріоритетних напрямів $є$ покращення індивідуального підходу до розвитку творчих здібностей спеціалістів з опорою на їх самостійну роботу. Саме самостійну роботу студентів за кредитно-модульної системи організації навчального процесу дозволяють організувати, направити та оцінити системи дистанційного навчання (СДН), які сьогодні займають своє вагоме місце на ринку освітніх послуг, а розвиток інфраструктури цифрових і мобільних комунікацій сприяє впровадженню в навчальний процес інноваційних технологій [2]. Необхідність створення СДН та їх ефективного впровадження на всіх освітніх рівнях усіх форм навчання визначено Законом України "Про основні засади розвитку інформаційного суспільства в Україні на 2007-2015 роки" [3]. Для розробки і орга- нізації СДН сьогодні застосовуються різноманітні програмні системи [4]. Прикладом комерційних програмних систем є "Black Board", "Lotus Learning Space", “WebTutor”, RATOS-AI ${ }^{\circledR}$, російські продукти компаній "ГиперМетод”, "Прометей” тощо. За відкритими ліцензіями розповсюджуються “Open Source Moodle”, "ILIAS", "Sakai", "Desire2Learn".

Необхідними умовами застосування дистанційних технологій навчання є наявність інфраструктури цифрових комунікацій, які лежать в основі єдиного інформаційного простору навчального закладу, готовність викладацького складу до впровадження цих технологій у навчальний процес, організаційна система розробки i контролю якості навчаючих та контролюючих комп'ютерних курсів тощо [5, 6]. Одним із найбілыш дискусійних видів навчальної діяльності студентів $є$ самостійна робота студентів. В умовах кредитно-модульної системи організації навчального процесу до неї відносять: підготовку до аудиторних занять, опрацювання розділів (тем), які не викладаються на аудиторних заняттях, виконання та захист індивідуальних завдань, оволодіння практичними навичками, підготовка до складання модульного контролю [7].

На сьогодні дещо в тіні залишаються питання висвітлення ролі нових технологій (СДН) у самопідго-

( І. Ю. Олійник 
товці студентів до ліцензійних інтегрованих іспитів (ЛII) “Крок 1", “Крок 2", “Крок 3” за кредитно-модульної системи організації навчального процесу.

Мета статті полягає саме у проведенні аналізу ефективності застосування СДН для самопідготовки студентів-стоматологів до складання ЛІІ “Крок 1. Стоматологія".

Основна частина. Модернізація освіти на засадах Болонської декларації потребує розробки ефективних засобів навчання і керування процесом навчання в нових умовах. Впровадження кредитно-модульної системи в медичну освіту привело до перерозподілу навчального часу в бік самостійної роботи. Саме тут актуальними є два шляхи їі спрямування: організація самостійної роботи студентів та контроль. Джерела педагогічної літератури підкреслюють, що контроль $€$ так званим “зворотним зв' язком” між викладачем вузу і студентом. За рахунок контролю знань педагог отримує інформацію про ефективність навчання з даного предмета чи окремої теми. Самостійна ж робота студентів із застосуванням СДН переважно має традиційний, загально визначений характер. Однак, окрім організації самостійної роботи студентів в традиційному (для кредитно-модульної системи навчання) руслі, ii спрямування може бути розширеним і для самопідготовки студентів до складання ЛІІ “Крок 1”, “Крок 2”, “Крок 3" тощо.

У Буковинському державному медичному університеті система дистанційного навчання "Moodle" використовується для самопідготовки до ЛІІ “Крок 1. Стоматологія" та iï контролю у студентів 3 курсу стоматологічного факультету вже два роки. Перші позитивні висновки про переваги застосування цієї системи дистанційного навчання можна зробити, провівши аналіз-порівняння відсотка (діаграма 1) успішного складання ЛІІ “Крок 1. Стоматологія” в 20092010 pp. (коли СДН “Moodle” не використовували для самопідготовки і контролю студентів-стоматологів) з результатами 2011-2012 pр. (де у процес підготовки студентів до ЛІІ “Крок 1. Стоматологія" було включено обов'язкову самопідготовку студентів та ii контроль у СДН “Moodle” БДМУ).

Безперечно, як позитивний результат використання СДН "Moodle" при самопідготовці студентів-стоматологів до складання ЛІІ “Крок 1. Стоматологія" (діаграма 2) можна вважати суттєве зменшення у 2011-2012 pр. порівняно з 2009-2010 рр. кількості студентів, які не склали з першого разу цей ЛІІ.

Порівняння результатів роботи студентів 3 курсів стоматологічного факультету при їх самопідготовці в СДН "Moodle" БДМУ з результатами складання ними ЛІІ “Крок 1. Стоматологія” (2011-2012 рр.) показує статистично достовірну розбіжність (діаграма 3) середнього показника (\%) по курсу, оскільки під час самопідготовки у СДН студенти можуть попередньо опрацювати тестові завдання 39 дисциплін, що входять до складу ЛII “Крок 1. Стоматологія” у навчальному та контролюючому режимах, а під час офіційного скла-

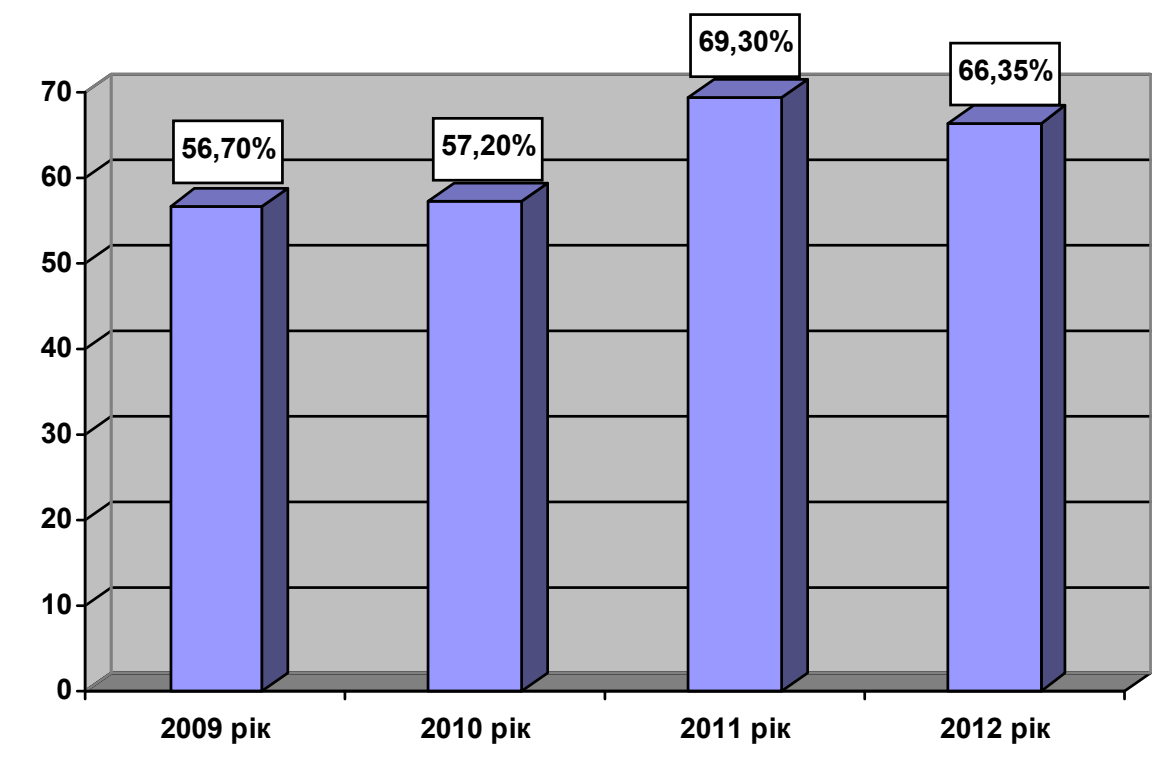

口Результат (\%) складання ЛІІ "Крок 1. Стоматологія" 2009-2012 рр.

Діаграма 1. Порівняння результатів складання студентами-стоматологами ЛІІ “Крок 1. Стоматологія" у 2009-2012 pp. (\%) 


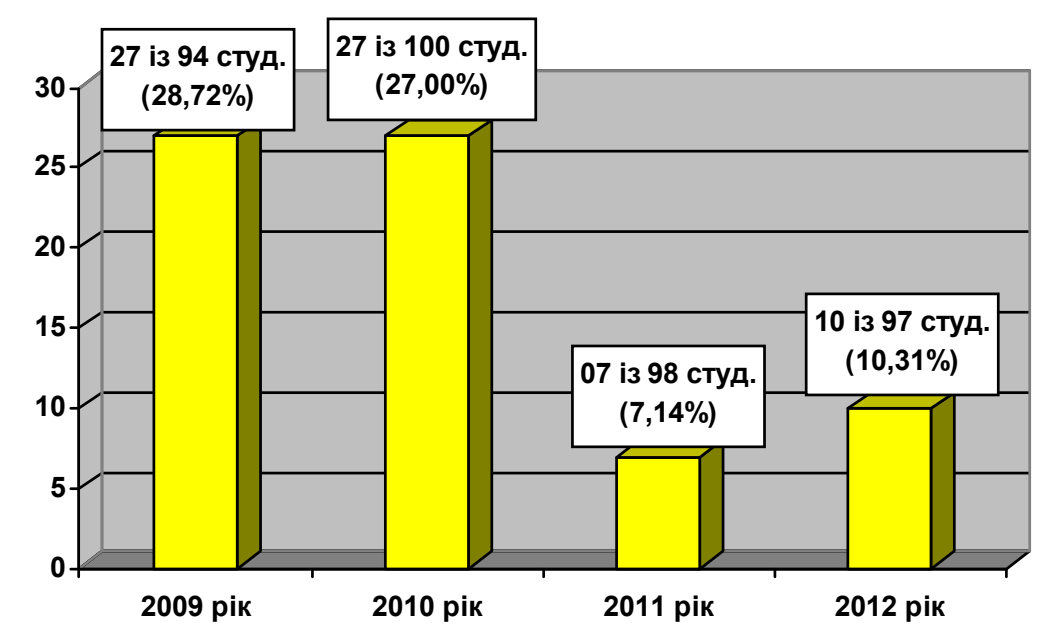

\section{$\square$ К-сть студентів, які не склали "Крок 1. Стоматологія" за першою спробою (2009-2012 рр.)}

Діаграма 2. Кількість студентів-стоматологів, які не склали за першою спробою ЛІІ “Крок 1. Стоматологія" у 2009-2012 pp.

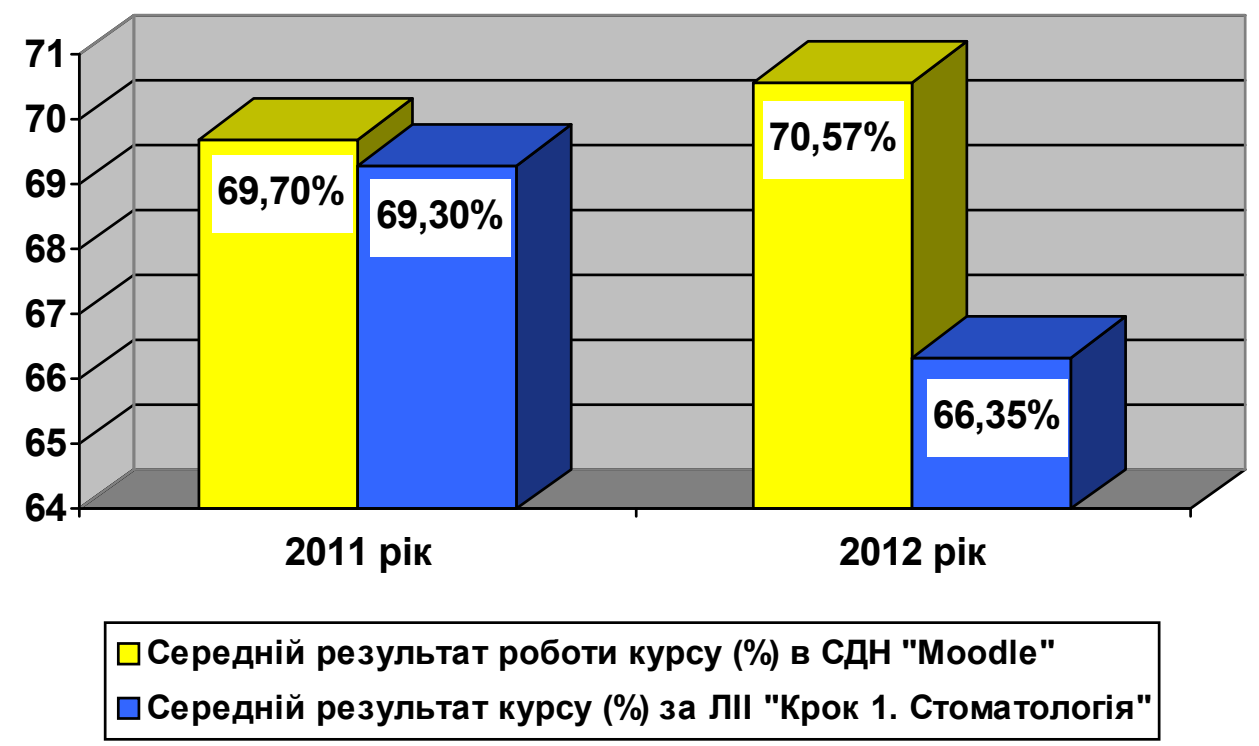

Діаграма 3. Порівняння результатів самопідготовки студентів 3 курсів стоматологічного факультету в СДН “Moodle” з результатами складання ними ЛІІ “Крок 1. Стоматологія” у 2011-2012рp.

(середній \% по курсу)

дання ЛІІ “Крок 1. Стоматологія” - працювали з ними вперше. Рівноцінна картина має місце при порівнянні результатів і по окремих академічних групах 3 курсів стоматологічного факультету за 2011-2012 pp.

Моніторинг якості підготовки студентів 3 курсу стоматологічного факультету до складання ЛІІ "Крок 1. Стоматологія" із використанням потужностей СДН "Moodle" БДМУ у жовтні 2011 року - лютому 2012 року підтвердив значимість ії безперервності та відкрив деякі недоліки.
Проведення, в ході самопідготовки студентів до складання ЛІІ “Крок 1. Стоматологія”, ряду проміжних контрольних зрізів показало позитивний вплив самопідготовки та контролю студентів-стоматологів при роботі у СДН на зростання відсотка (\%) засвоєння виставленого у навчальному та контролюючому режимах СДН "Moodle" матеріалу.

Водночас ми не повинні випускати з уваги кілька суттєвих моментів, які слід віднести до недоліків організації самопідготовки студентів до ЛІІ “Крок 1. 
Стоматологія" та дистанційного контролю ії якості 3 використанням СДН "Moodle". По-перше, нам не вдалось ще підняти самосвідомість студентів-третьокурсників до такого рівня, щоб досягнути 100 \% регулярної їх участі у роботі університетської СДН. Це, в свою чергу, знаходить відображення у тому, що ряд студентів ухиляється від контролю свого рівня знань тест-системою, а результат працюючих у ній студентів із кращим рівнем підготовки (ніж тих, які допускають ухиляння) робить сумарний результат групи чи курсу дещо завищеним порівняно з фактично наявним рівнем. По-друге, недостатня самосвідомість окремих студентів та бажання при цьому отримати хороший результат контрольних тестувань у СДН призводить, очевидно, до обманного виконання контрольних дистанційних тестувань більш підготовленими у теоретичному плані студентами, яких залучають слабші за рівнем підготовки студенти (із входом у СДН під їхніми логінами та паролями). Саме такими діями, очевидно, слід пояснити разючу розбіжність між результатом контрольних тестувань окремих студентів у СДН “Moodle" та результатами ї письмових контрольних зрізів за одними і тими ж базами тестових завдань. По-третє, існує, хоч і незначна група студентів (близько 2-3 \%), яка все ще не має постійного доступу до мережі Інтернет та не використовує університетську комп'ютерну базу для роботи у СДН "Moodle" аргументуючи це тим, що готується до складання ЛІІ “Крок 1. Стоматологія" лише за буклетами та практикумами 3 підготовки до ЛІІ.

\section{Література}

1. Півторак К. В. Формування особистості та мотивації до навчання у студентів медичного університету / К. В. Півторак, I. В. Феджага// Медична освіта. - 2011. - №4. - С. 28-31.

2. Колесник Ю. М. Інформатизація ЗДМУ : підсумки, проблеми, перспективи / Ю. М. Колесник, О. А. Рижов // Актуальні питання дистанційної освіти та телемедицина 2009 : матеріали Всеукраїнської науково-практичної відеоконференції, 16-17 квітня 2009 р. - Запоріжжя : Вид-во ЗДМУ, 2009.- - . 4-7.

3. Закон Верховної Ради України № 537-V“"Про основні засади розвитку інформаційного суспільства в Україні на 2007-2015 роки". - Офіційне видання Відомості Верховної Ради України. - 2007. - № 12. - 102 c.

4. Рижов А. О. Інтелектуальна адаптивна система дистанційного навчання RATOS-AI ${ }^{\circledR}$. (Частина 1). Концеп-
Сучасна вища школа не може дати майбутньому спеціалісту безмежного об' єму знань. Але вона може та повинна фундаментально підготувати його до сприйняття потреби до самоосвіти. Вона повинна орієнтуватися на зміни традиційних форм навчальних занять. У цьому ракурсі суттєвим і ще зовсім не задіяним резервом, на наш погляд, $є$ раннє і активне залучення студентів 1-го і 2-го курсів стоматологічного факультету базовими для ЛІІ “Крок 1. Стоматологія" кафедрами до самостійної роботи з підготовки та контролю їх знань у СДН “Moodle”. Останне послужить вагомим аргументом у формуванні самосвідомості студентів та вихованні почуття відповідальності за свою підготовку до ЛІІ “Крок 1. Стоматологія" перед медичним університетом, батьками та суспільством.

Висновки. Використання студентами-стоматологами системи дистанційного навчання "Moodle" для самопідготовки до ліцензійного інтегрованого іспиту "Крок 1. Стоматологія" та її контролю сприяє покращенню рівня підготовки та досягненню більш високих їі результатів.

Практичний досвід такої самопідготовки студентів з іiї контролем у системі дистанційного навчання сприяє формуванню клінічного мислення і, як наслідок - здобуттю професійних знань.

Виховання у студентів усвідомлення потреби самопідготовки та ії контролю із використанням системи дистанційного навчання "Moodle" сприяє зростанню рівня готовності до складання ними ЛІІ “Крок 1. Стоматологія".

ція системи / А. О. Рижов // Запорожский медицинский журнал. -2010. - Т. 12, № 1.-С. 23-27.

5. Титенко С. В. Освітні інтернет-системи та моделювання знань / С. В. Титенко // Лабораторія СЕТ. - Київ, 2006. Режим доступу до журналу: http: // www.setlab. net/ ?view=AIED Overview.

6. Рыбина Г. В. Обучающие интегрированные экспертные системы : некоторые итоги и перспективы / Г. В. Рыбина // Искусственный интеллект и принятие решений. 2008. - № 1.- С. 22-46.

7. Досвід організації самостійної роботи студентів при впровадженні кредитно-модульної системи навчання на кафедрі патологічної анатомії та судової медицини / І. С. Шпонка, Г. С. Кириленко, С. В. Козлов [та ін.] // Медична освіта. - 2010. - № 4. - С. 106-108. 